\title{
Antileishmanial Activity of Coumarin from Amburana cearensis Seeds
}

\author{
Roxeane Martins Monteiro ${ }^{*}$, Igor de Sá Carneiro², Felipe Domingos de Sousa1,3, \\ Maria Jania Teixeira", Regina Claudia Matos Dourado', Renato de Azevedo Moreira1,3, \\ Ana Cristina de Oliveira Monteiro Moreira ${ }^{1}$
}

\author{
${ }^{1}$ Núcleo de Biologia Experimental (NUBEX), Centro de Ciências da Saúde, Universidade de Fortaleza, Fortaleza, Brazil \\ ${ }^{2}$ Laboratório de Biologia Molecular e do Desenvolvimento, Universidade de Fortaleza, Fortaleza, Brazil \\ ${ }^{3}$ Departamento de Bioquímica e Biologia Molecular, Universidade Federal do Ceará, Fortaleza, Brazil \\ ${ }^{4}$ Departamento de Patologia e Medicina Legal, Universidade Federal do Ceará, Fortaleza, Brazil \\ Email: *rox@unifor.br
}

How to cite this paper: Monteiro, R.M., de Sá Carneiro, I., de Sousa, F.D., Teixeira, M.J., Dourado, R.C.M., de Azevedo Moreira, R. and de Oliveira Monteiro Moreira, A.C. (2017) Antileishmanial Activity of Coumarin from Amburana cearensis Seeds. Open Access Library Journal, 4: e3829.

https://doi.org/10.4236/oalib.1103829

Received: July 16, 2017

Accepted: November 27, 2017

Published: November 30, 2017

Copyright $\odot 2017$ by authors and Open Access Library Inc.

This work is licensed under the Creative Commons Attribution International License (CC BY 4.0).

http://creativecommons.org/licenses/by/4.0/

\begin{abstract}
Visceral leishmaniasis is caused by parasites of the genus Leishmania. Prevalent in developing countries, the disease is on the list of the world's most neglected diseases. Most cases (90\%) in Latin America occur in Brazil, especially in the Northeast. The condition is treated mainly with pentavalent antimonials, an expensive and relatively inefficient drug known to induce resistance. In search of new antileishmanial drugs, much attention has been given to the medicinal properties of coumarin. In this study, coumarin was isolated from seeds of Amburana cearensis, purified and evaluated with regard to its ability to inhibit Leishmania chagasi promastigotes using the MTT test. The cell viability of macrophages treated with coumarin was also evaluated. The findings were submitted to one-way ANOVA for paired data, followed by the Bonferroni correction. The level of statistical significance was set at $5 \%(p<0.05)$. Coumarin displayed low toxicity to macrophages in the MTT test $(p>0.05)$, but was toxic to Leishmania chagasi promastigotes $(p<0.05)$. Our results represent a contribution to the development of new drugs for the control or prophylaxis of visceral leishmaniasis.
\end{abstract}

\section{Subject Areas}

Parasitology

\section{Keywords}

Leishmaniasis, Coumarin, Amburana cearensis, Cell Viability 


\section{Introduction}

Leishmaniasis is a zoonotic disease caused by protozoa of the genus Leishmania. The parasite undergoes two development stages, one in the cells of the human mononuclear phagocyte system (amastigotes) and one in invertebrates (promastigotes) [1]. Classified as a "neglected disease", the condition is prevalent in socioeconomically challenged populations, especially in developing countries. About 12 million people are affected worldwide, with approximately 2 million new cases of the clinical form and 60,000 deaths each year [2].

Visceral leishmaniasis (VL) is distributed worldwide. A Latin American form of the disease named American visceral leishmaniasis (AVL), or neotropical kala-azar, has been registered in at least 12 countries, with $90 \%$ of the reports coming from Brazil, especially from the Northeast [3]. Between 2006 and 2010, 18,168 new cases of VL were reported in Brazil, $47.1 \%$ of which from the Northeast [3]. In this country, Leishmania (L) infantum chagasi is the etiologic agent of visceral leishmaniasis [4]. Transmission occurs between humans and dogs bitten by infected sandflies of the genus Lutzomyia [5].

Leishmaniasis is treated mainly with pentavalent antimonials, with a success rate of $26 \%$ - $100 \%$. However, the use of this medication is limited by serious side effects and parasite resistance [6]. Pentamidine or Amphotericin B is the choice of treatment in such cases [7]. Lately, much attention has been given to the search for phytotherapeutic compounds with potential antileishmanial activity [8]. In Brazil, about 80,000 species of plants with medicinal properties have been described. Coumarin is found in several of these [9].

Amburana cearensis (Allemão) AC Smith is native to Northeastern Brazil but is currently widely distributed in South America, including regions of Argentina and Bolivia. Its bark and seeds have long been used to prepare homemade remedies for respiratory illnesses [10].

The tree produces coumarin, a biologically active compound with antileishmanial properties [11]. In the present study, we evaluated the antileismananial activity of coumarin isolated from seeds of Amburana cearensis by testing for cell viability. The study is intended as a contribution to the development of new drugs for the control or prophylaxis of visceral leishmaniasis.

\section{Materials and Methods}

\subsection{Plant Material}

Seeds of Amburana cearensis were harvested in the month of January 2009, 2010 and 2011 from plants growing in Quixeramobim (a hinterland municipality in Ceará, Northeastern Brazil). Figure 1 shows Amburana cearensis seeds. A voucher specimen was deposited at Prisco Bezerra herbarium (Department of Biology, Federal University of Ceará) under no. 51673.

\subsection{Extraction and Chromatographic and Spectroscopic Identification}

The collected seeds were fragmented and defatted with hexane. The dried seed 


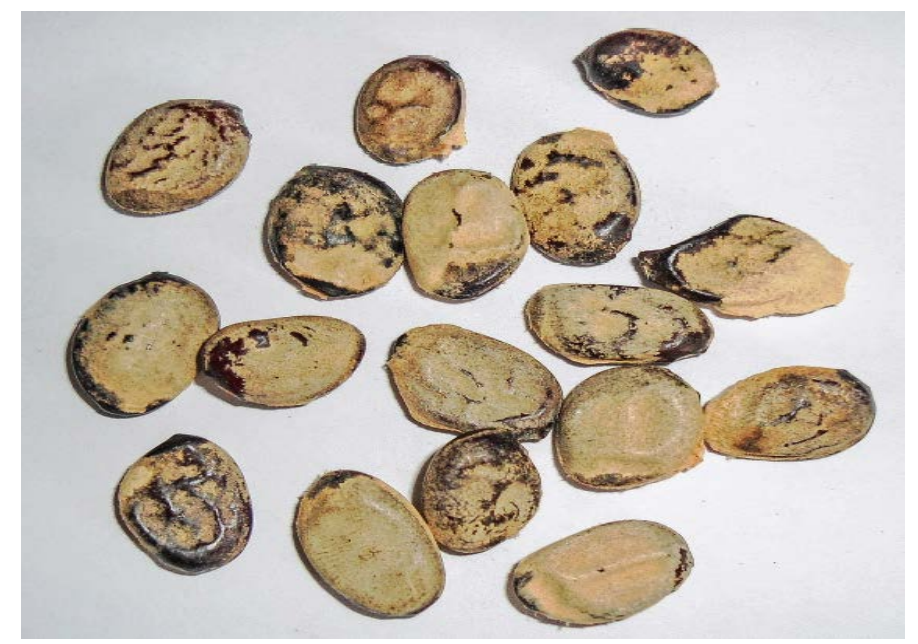

Figure 1. Amburanacearensis seeds.

powder was extracted overnight with $0.15 \mathrm{M} \mathrm{NaCl}$ under refrigeration at $8^{\circ} \mathrm{C}$. The extract was centrifuged at $10,000 \times \mathrm{g}$ for $30 \mathrm{~min}$ and filtered in membrane with pore $0.45 \mu \mathrm{m}$.

Coumarin was extracted by partition from the total extract using chloroform. An $80-\mathrm{mL}$ aliquot was placed in a separatory funnel and homogenized with 90 $\mathrm{mL}$ of chloroform. The coumarin present in the organic phase was collected in a beaker with anhydrous sodium sulfate and then transferred to a tared becker. The sample was covered with aluminum foil and left at room temperature overnight to dry the sample. The mass of coumarin was established by calculating the difference between the weight of the empty becker and the dry sample. Coumarin was submitted to thin-layer chromatography (TLC) for identification. To do so, a cellulose acetate plate with a sample of the extracted coumarin and a control sample of $>99 \%$ pure standard coumarin $\left(\right.$ Sigma ${ }^{\circ}$ ) were analyzed in a chamber under UV light at $365 \mathrm{~nm}$. The mobile phase consisted of chloroform and ethyl acetate (1:1) [12].

The structure of the extracted compound was determined by analysis of nuclear magnetic resonance (NMR). The proton nuclear magnetic resonance $\left({ }^{1} \mathrm{H}\right.$ $\mathrm{NMR})$ and carbon-13 magnetic resonance $\left({ }^{13} \mathrm{C} \mathrm{NMR}\right)$ spectra were obtained on a Bruker Avance (DPX-300) spectrometer belonging to the Northeastern Center for the Application and Use of Nuclear Magnetic Resonance of the Federal University of Ceará (CENAUREMN/UFC).

For the determination of ${ }^{1} \mathrm{H}$ and ${ }^{13} \mathrm{C}$, the sample $(20 \mu \mathrm{g})$ was diluted in $0.6 \mathrm{~mL}$ aliquots of deuterated solvent: chloroform $(\mathrm{CDCl} 3) \mathrm{ACROS}^{\circ}$; water (D2O)

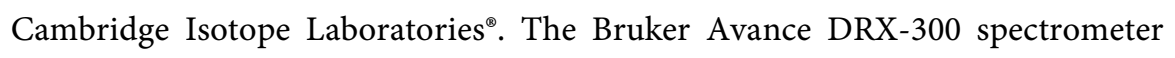
with a $5 \mathrm{~mm}$ reverse detection probr and $7046 \mathrm{~T}$ magneto was operated on the frequencies of 300.13 and $75.47 \mathrm{MHz}$ respectively.

Chemical shifts $(\delta$ ) were expressed were expressed in parts per million (ppm) according to spectra. The proton spectra were referenced by peaks of the hydrogens belonging to the non-deuterated residual molecules of the solvent borne 
(chloroform- $\delta 7.27$ ). While for the carbon-13 spectra, the shifts were referenced by chemical shifts of the central chloroform carbon-13 peaks ( $\delta 77.23)$.

In the ${ }^{1} \mathrm{H}$ and ${ }^{13} \mathrm{C}$ experiments, the values for the acquisition parameters, respectively: spectral widths of 24 and $260 \mathrm{ppm}$; relaxation time of $1 \mathrm{~s}$ and $90^{\circ}$ pulse width of 9.60 us $(0 \mathrm{~dB})$ and 10.90 us $(-3 \mathrm{~dB})$. To obtain the data, the programs ${ }^{1} \mathrm{H}(\mathrm{zg}),{ }^{13} \mathrm{C}-\mathrm{BB}$ (zppg), 13C-DEPT135 (dept135) were used. The DEPT (Distortionless Enhancement by Polarization Transfer) method was used to determine the

${ }^{13} \mathrm{C}$ NMR hydrogenation pattern as follows: $\mathrm{C}$ (non-hydrogenated carbon), $\mathrm{CH}$ (methylene carbon), $\mathrm{CH}_{2}$ (methylene or methylidene carbon) and $\mathrm{CH}_{3}$ (methyl carbon).The characterization of the non hydrogenated carbons was done by subtracting the DEPT 135 spectrum from the BB spectrum [13].

\subsection{Cytotoxicity Assay}

Macrophages (AMJ2C11) were obtained from the cell bank (BCRJ) of the Federal University of Rio de Janeiro (UFRJ). The cells were cultured in $75 \mathrm{~cm}^{2}$ plates with DMEM medium supplemented with $10 \%$ foetal calf serum, L-glutamine and penicillin and incubated at $37^{\circ} \mathrm{C}$ in an atmosphere of $5 \% \mathrm{CO}_{2}$ and $100 \%$ humidity. For the in vitro tests, the confluent cell monolayer was trypsinized, washed with culture medium, distributed in sterile flat-bottomed 96-well plates and incubated at $37^{\circ} \mathrm{C}$ for $24 \mathrm{~h}$ to ensure cell adherence.

Leishmania chagasi promastigotes (MHOM/2002/LPC-RPV BR) were obtained from the Leishmania collection of the Oswaldo Cruz Institute (CLIOC). The cells were cultured in culture bottles filled with Schneider medium supplemented with $10 \%$ foetal calf serum and incubated at $22^{\circ} \mathrm{C}$ in an atmosphere of $5 \% \mathrm{CO}_{2}$ and $100 \%$ humidity.

Cytotoxicity was evaluated with the 3-(4,5-dimethylthiazol-2-yl)-2,5-diphenyltetrazolium bromide (MTT) reduction method. Macrophages $(4 \times 107$ cells/well) and promastigotes $\left(10^{6}\right.$ cells/well $)$ were incubated in $100 \mu \mathrm{L}$ coumarin solution at five different concentrations $(25,50,100,250$ and $500 \mathrm{mg} / \mathrm{mL})$. The plates were incubated for 24 hours in an atmosphere of $5 \% \mathrm{CO}_{2}$ at $37^{\circ} \mathrm{C}$ (macrophages) or $22^{\circ} \mathrm{C}$ (promastigotes). Suspensions of macrophages and non-treated Leishmania were used as negative controls. For the MTT assay, the plates were centrifuged, the supernatant was carefully removed from the wells, $200 \mu \mathrm{L}$ MTT solution (10\%) was added and the plates were incubated for another 3 hours. Subsequently, the plates were centrifuged, the supernatant was removed and $150 \mu \mathrm{L}$ DMSO was added to the wells to lyse the cells and solubilize the formazan, with thorough mixing. The optical density at $540 \mathrm{~nm}$ was determined using an ELISA reader (Biotek ${ }^{\circledast}$.

The MTT test evaluates mitochondrial viability by quantifying mitochondrial reduction of MTT to formazan. Reduced optical density indicates decreased cell viability. The absorbance obtained from non-treated cells was considered as $100 \%$ cell viability. Cell viability was expressed as the percentage of absorbance 
obtained from untreated control cells and treated cells after subtracting the background absorbance (DMSO). All tests were conducted sixfold on three different days [13].

\subsection{Statistical Analysis}

The results of the in vitro tests were analyzed with the software Graph Pad Prism $^{\oplus}$ 6.0. Mean values \pm standard error of the mean (SEM) for each group were entered in a bar chart for comparison. Differences between treatments were analyzed with one-way ANOVA for paired data, followed by the Bonferroni correction. The level of statistical significance was set at $5 \%(p<0.05)$.

\section{Results}

In this study, we evaluated the antileishmanial activity of coumarin isolated from seeds of Amburana cearensis. The crude extract yielded $0.0145 \mathrm{~g}$ of coumarin. Characterized by a pattern of intense fluorescence under UV light at $365 \mathrm{~nm}$, the chromatographic profile of the sample was similar to that of pure standard coumarin.

The isolated coumarin was identified as 1,2 benzopyrone by comparing the results of $1 \mathrm{H}$ and $13 \mathrm{C}$ NMR. The Figure 2 shows the $1 \mathrm{H}$ NMR profile of the coumarin spectrum $\left(300 \mathrm{MHz}, \mathrm{CDCl}_{3}\right.$ ) featured two multiplets at $\delta 7.51$ and $7.29(2 \mathrm{H}, \mathrm{m})$ linked to aromatic hydrogens.

The Figure 3 shows the two doublets observed at $\delta 7.71$ and $6.42(1 \mathrm{H}, \mathrm{d}, \mathrm{J}=$ $9.5 \mathrm{~Hz})$ were related to cis-olefinic protons. On 13C NMR $\left(75 \mathrm{MHz}, \mathrm{CDCl}_{3}\right)$ nine spectral lines were visible. The line at $\delta 160.9(\mathrm{C}-2)$ was associated with $\alpha, \beta$-un-
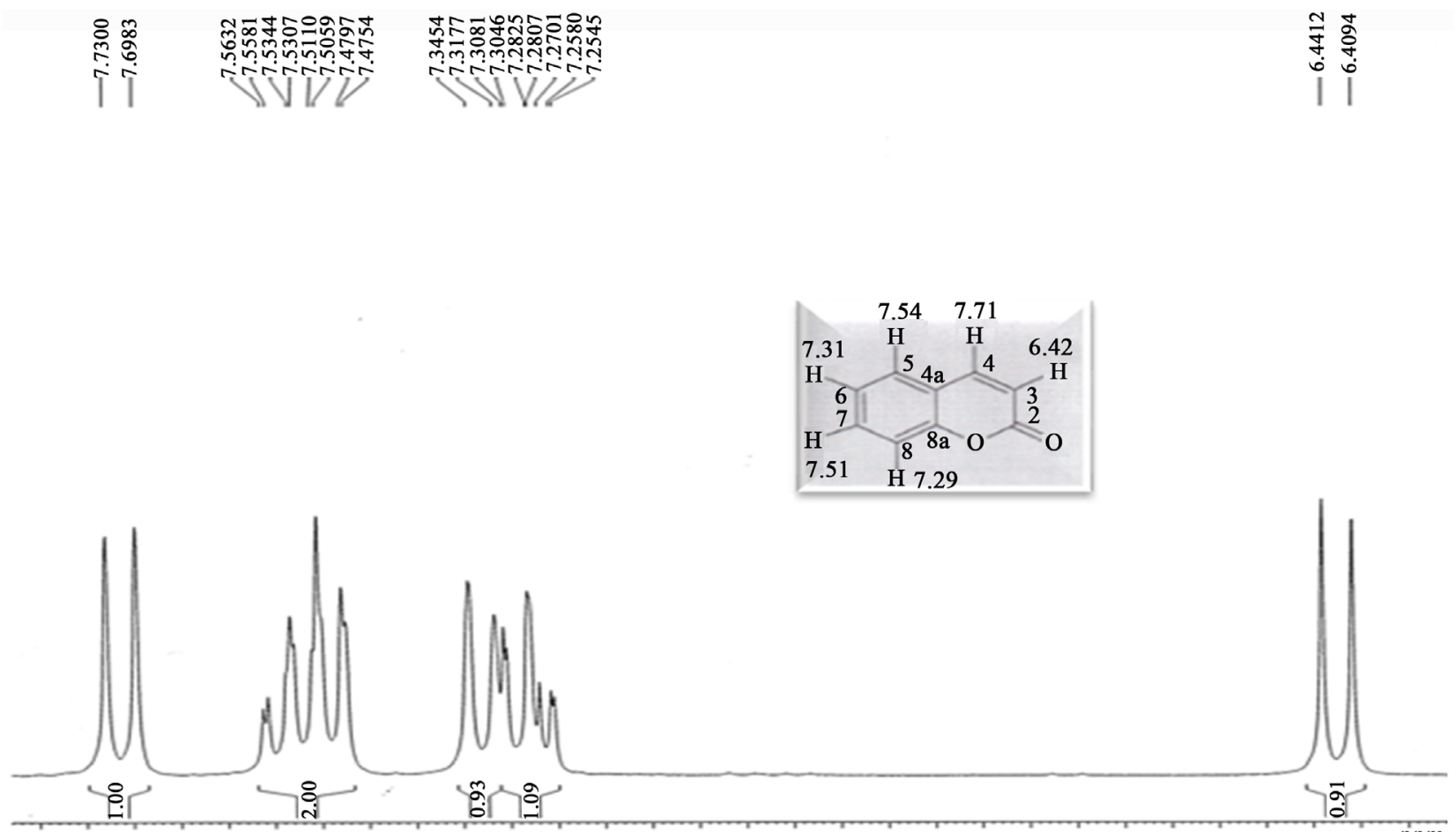

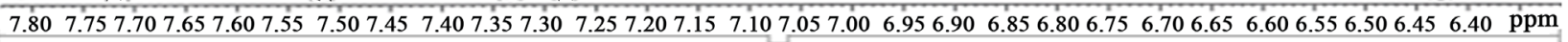

Figure 2. $1 \mathrm{H} \mathrm{NMR}$ spectrum $(\mathrm{CDCl} 3,300 \mathrm{MHz})$ of coumarin isolated from an aqueous extract of seeds of Amburana cearensis. 

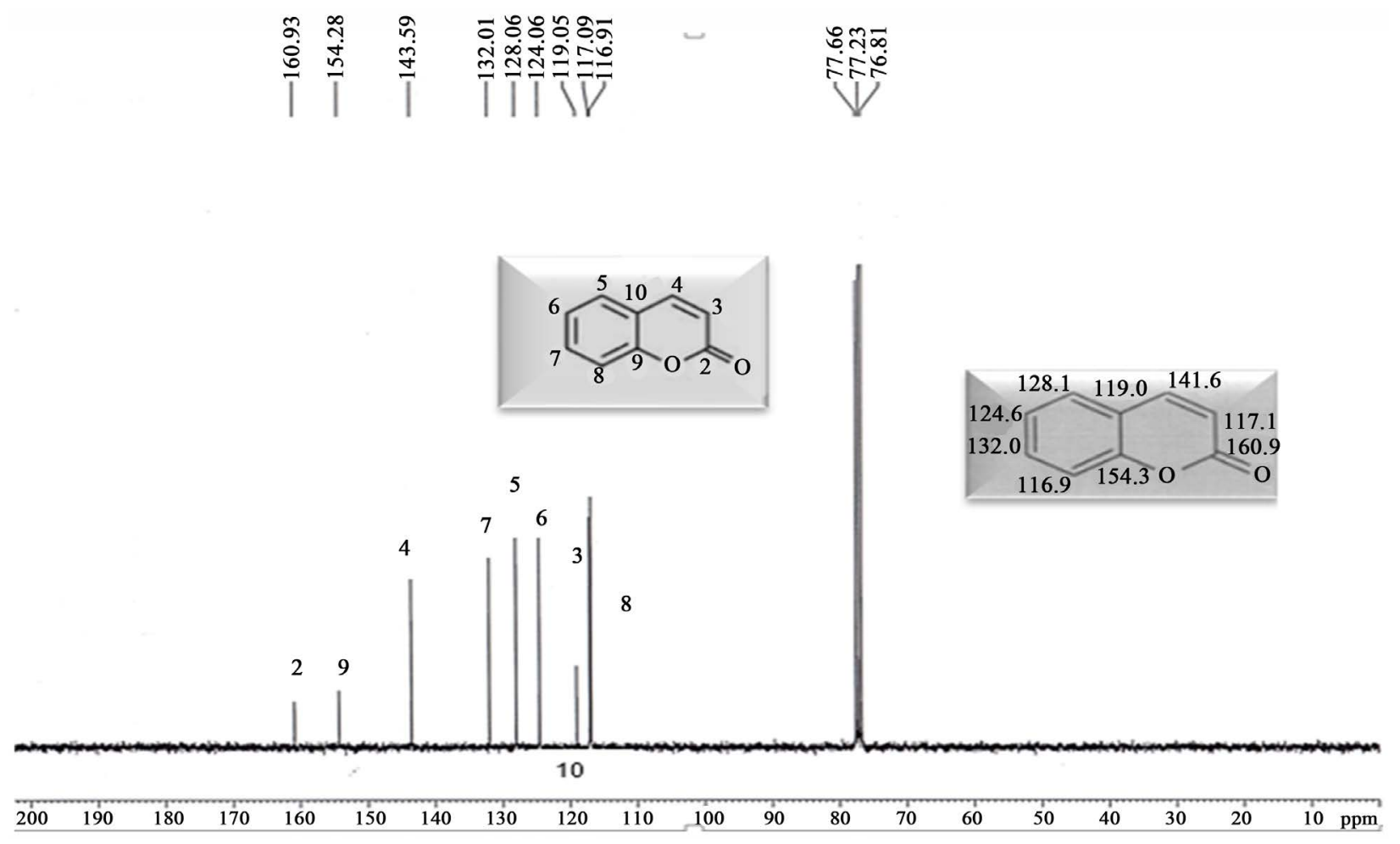

Figure 3. Composite pulse-decoupled 13C NMR spectrum ( $\mathrm{CDCl} 3,75 \mathrm{MHz})$ of coumarin isolated from an aqueous extract of seeds of Amburana cearensis.

saturated lactone carbonyl, while the others were attached to sp2 carbons $(\delta$ 154.3 - 116.9).

The Table 1 demonstrates the results of the NMR scan allowed to deduce the molecular formula of coumarin $\left(\mathrm{C}_{9} \mathrm{H}_{6} \mathrm{O}_{2}\right)$ as being composed of a benzene ring and an $\alpha, \beta$-unsaturated lactone ring (Table 1 ).

In the cytotoxicity test, $L$. chagasi promastigotes were challenged in vitro with coumarin solutions at different concentrations $(25,50,100,200$ and $500 \mu \mathrm{g} / \mathrm{mL})$. Figure 4 shows that none of the coumarin concentrations displayed toxicity against macrophages $(p>0.05)$.

All coumarin concentrations $(25,50,100,250$ and $500 \mu \mathrm{g} / \mathrm{mL})$ presented antileishmanial activity when compared to untreated control Leishmania $(p<0.05)$. As shown in Figure 5, the antileishmanial activity of the coumarin solutions used in this study was not dose-dependent: the effect was statistically similar for all the concentrations tested $(25,50,100,250$ and $500 \mu \mathrm{g} / \mathrm{mL})$.

As shown in Figure 5, the antileishmanial activity of the coumarin solutions used in this study was not dose-dependent: the effect was statistically similar for all the concentrations tested $(25,50,100,250$ and $500 \mu \mathrm{g} / \mathrm{mL})$.

\section{Discussion}

Known for its medicinal properties, coumarin (1,2 benzopyrone) has been isolated from many different plant species, including Amburana cearensis [14]. Extracts from the bark and seeds of this tree are used to treat disorders of the res- 


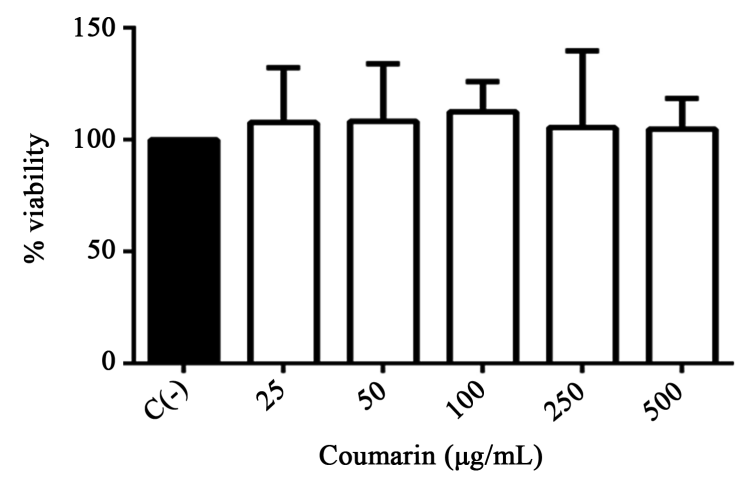

Figure 4. Macrophages challenged with coumarin isolated from seeds of Amburana cearensis. No statistically significant difference was observed between the groups $(p>0.05)$. The bars represent mean values \pm standard error of the mean (SEM) in each group. After subtracting the background absorbance (DMSO), the data were analyzed with ANOVA followed by the Bonferroni correction. $\mathrm{C}(-)=$ negative control.

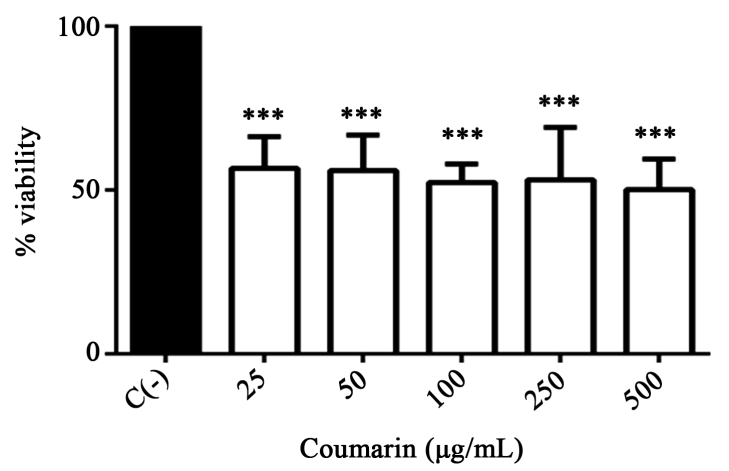

Figure 5. Leishmania chagasi promastigotes challenged with coumarin isolated from seeds of Amburana cearensis at different concentrations. The bars represent mean values \pm standard error of the mean (SEM) in each group. The experiment was conducted six-fold on three different days. After subtracting the background absorbance (DMSO), the data were analyzed with ANOVA followed by the Bonferroni correction. ${ }^{\star}=p<0.001$ in relation to the negative control C(-).

Table $1 .{ }^{13} \mathrm{C}$ NMR profile of coumarin isolated from an aqueous extract of seeds of $\mathrm{Am}$ burana cearensis compared to 13C NMR profiles from two other studies.

\begin{tabular}{cccc}
\hline$\# \mathrm{C}$ & $\begin{array}{r}\text { Coumarin (Pouchert) } \\
\delta_{\mathrm{c}}(\mathrm{ppm}) \mathrm{CDCl}_{3}\end{array}$ & $\begin{array}{c}\mathrm{ACS}-1(\text { Canuto }) \\
\delta_{\mathrm{c}}(\mathrm{ppm}) \mathrm{CDCl}_{3}\end{array}$ & $\begin{array}{c}\text { Current study } \\
\delta_{\mathrm{c}}(\mathrm{ppm}) \mathrm{CDCl}_{3}\end{array}$ \\
\hline 2 & 160.6 & 160.9 & 160.9 \\
3 & 116.4 & 117.1 & 117.0 \\
4 & 143.3 & 141.6 & 143.5 \\
5 & 127.7 & 128.1 & 128.0 \\
6 & 124.3 & 124.6 & 124.6 \\
7 & 131.6 & 132.0 & 132.0 \\
8 & 116.6 & 116.9 & 116.9 \\
9 & 118.8 & 119.9 & 119.5 \\
10 & 153.8 & 154.3 & 154.2 \\
\hline
\end{tabular}


piratory tract and to relieve spasms and rheumatic pain [15]. Most phytochemical studies of $A$. cearensis have focused on compounds isolated from the bark, especially coumarin [15].

Spectral data for coumarin isolated from $A$. cearensis have been published before [16]. Based on ethanol extracts of seeds, [17] used NMR data to deduce the molecular formula of coumarin $\left(\mathrm{C}_{9} \mathrm{H}_{6} \mathrm{O}_{2}\right)$. This formula was confirmed in the present study by ${ }^{1} \mathrm{H}$ and ${ }^{13} \mathrm{C}$ NMR imaging.

The previously reported high level of activity of coumarim from seeds of $A$. cearensis against $L$. chagasi was confirmed in our experiments. [18] and [19] found coumarin extracted from the bark of $A$. cearensis to be efficient against Leishmania amazonensis, L. braziliensis and L. donovani at a concentration of $50 \mu \mathrm{g} / \mathrm{mL}$. In addition, coumarin displayed antileishamanial action against $L$. chagasi at a concentration of $73 \mathrm{mg} / \mathrm{mL}$ [19]. To evaluate the antileishmanial activity of coumarin (-) mammea A/BB isolated from extracts of the leaves of $\mathrm{Ca}$ lophyllum brasiliensis, L. amazonensis promastigotes were challenged with 3.0 $\mathrm{mg} / \mathrm{mL}$ (-) mammea A/BB for 72 hours. On electron microscopy, ultrastructural changes were observed, including binucleated cells, multiple vacuolation, intense exocytic activity in the flagellar pocket region and swollen mitochondria with concentric membranes in the mitochondrial matrix [20].

The coumarin solutions tested in this study displayed no toxicity against macrophages in vitro. Macrophages are the target cells for Leishmania. They provide nutrients for amastigote development and favor the establishment of infection [21]. Phagocytosis occurs by adhesion of Leishmania promastigotes to macrophages by way of lectin-like ligands in the membrane. The induction of immune response involves the processing of antigenic material and the presentation to lymphocytes of this material on macrophage surfaces following phagocytosis and digestion [22]. Essentially, the parasite restricts the action of the immune system and inhibits the microbicidal action of the macrophages [23]. The presence of the parasite leads to defects in macrophage-lymphocyte cooperation, making leishmaniasis a difficult-to-treat condition [24].

In conclusion, leishmaniasis is a neglected disease, the treatment of which has remained unaltered for over 60 years despite serious side effects and the worldwide emergence of drug resistance. New strategies and therapies are needed to prevent and treat leishmaniasis. In vitro tests of leishmanicidal compounds extracted from plants like Amburana cearensis is a promising line of study towards the development of new antileishmanial drugs. The present study confirmed the antileishmanial activity of coumarin against $L$. chagasi promastigotes in vitro.

\section{Acknowledgements}

We thank CENAUREMN [Northeastern Center for the Application and Use of Nuclear Magnetic Resonance, Federal University of Ceará] for the NMR spectra of coumarin, and CLIOC [the Leishmania Collection of the Oswaldo Cruz Institute] for the donation of Leishmania cells. 


\section{References}

[1] Gontijo, B. and de Carvalho, M.L.R. (2003) American Cutâneous Leishmaniasis. Revista da Sociedade Brasileira de Medicina Tropical, 36, 71-78. https://doi.org/10.1590/S0037-86822003000100011

[2] World Health Organization (2007) Control of Leishmaniasis. WHO, Geneve, 4 p.

[3] Brazil (2010) Ministério da Saúde, Secretaria de Vigilância em Saúde. [Ministry of Health, Secretariat of Health Surveillance.] Epidemiological Bulletin, 2,11-13.

[4] Carvalho, M.R., Valença, H.F., da Silva, F.J., de Pita-Pereira, D., de Araújo-Pereira, T., Britto, C., Brazil, R.P. and Brandão-Filho, S.P. (2010) Natural Leishmania Infantum Infection in Migonemyia Migonei (França, 1920) (Diptera: Psychodidae: Phlebotominae) the putative vector of visceral leishmaniasis in Pernambuco State, Brazil. Acta Tropica, 116, 108-110. https://doi.org/10.1016/j.actatropica.2010.03.009

[5] Madeira, M.F., Marzochi, M.C.A., Schubach, A.O., Schubach, T.M.P., Pacheco, R.S. and Oliveira, F.S. (2006) Mixed Infection with Leishmania (Viannia) braziliensis and Leishmania (Leishmania) chagasi in Naturally Infected Dog from Rio de Janeiro, Brazil. Transactions of The Royal Society of Tropical Medicine and Hygiene, 100, 442-445. https://doi.org/10.1016/j.trstmh.2005.07.011

[6] Rodrigues, A.M., Hueb, M., dos Santos, T.A.R.R. and Fontes, C.J.F. (2006) Fatores associados ao insucesso do tratamento da leishmaniose cutânea com antimoniato de meglumina. [Factors Associated with Treatmet Failure of Cutaneous Leishmaniasis with Meglumine Antimoniate.] Revista da Sociedade Brasileira de Medicina Tropical, 39, 139-145. https://doi.org/10.1590/S0037-86822006000200001

[7] Name, R.Q., Borges, K.T., Nogueira, L.S.C., Sampaio, J.H.D., Tauif, P.L. and Sampaio, R.N. (2005) Estudo clínico, epidemiológico e terapêutico de 402 pacientes com leishmaniose tegumentar americana atendidos no Hospital Universitário de Brasília, DF, Brasil. Anais Brasileiros De Dermatologia, 80, 249-254.

https://doi.org/10.1590/S0365-05962005000300004

[8] Gachet, M.S., Lecaro, J.S., Kaiser, M., Brum, R., Navarrete, H., Muñoz, R.A., Bauer, R. and Schühly, W. (2010) Assement of Anti-Protozoal Activity of Plants Traditionally Used in Ecuador in Treatment of Leishmaniasis. Journal of Ethnopharmacology, 128, 184-197. https://doi.org/10.1016/j.jep.2010.01.007

[9] Braga, F.G., Bouzada, M.L., Fabri, R.L., Matos, M.O., Moreira, F.O., Elita, S. and Coimbra, E.S. (2007) Antileishamanial and Antifungal Activity of Plants Used in Traditional Medicine in Brazil. Journal of Ethnopharmacology, 111, 396-402. https://doi.org/10.1016/j.jep.2006.12.006

[10] Ramos, K.M.O., Felfili, J.M., Fagg, C.W., Sousa-Silva, J.C. and Franco, A.C. (2004) Desenvolvimento inicial e repartição de biomassa de Amburana cearensis (Allemao) A.C. Smith, em diferentes condições de sombreamento. [Initial Growth and Biomass Allocation of Amburana cearensis (Allemao) A.C. Smith, under Different Levels of Shade.] Acta Botanica Brasilica, 18, 351-358. https://doi.org/10.1590/S0102-33062004000200014

[11] Leal, L.K.A.M., Nechio, M., Silveira, E.R., Canuto, K.M., Fontenele, R.A. and Viana, G.S.B. (2003) Anti-Inflamatory and Smooth Muscle Relaxant Activities of the Hydralcholic Extract and Chemical Constituents from Amburana cearensis A C Smith. Phytotherapy Research, 17, 335-340. https://doi.org/10.1002/ptr.1139

[12] Matos, F.J.A. (2009) Introdução a fitoquímica experimental. [Introduction to experimental phytochemistry.] 3rd ed., Edições UFC, Fortaleza, 147 p.

[13] Mosmann, T. (1983) Rapid Colorimetric Assay for Cellular Growth and Survival. 
Journal of Immunological Methods, 65, 55-63.

[14] Costa-Lotufo, L.V., Jimenez, P.C., Wilke, D.V., Leal, L.K.A.M., Cunha, G.M.A., Silveira, E.R., Canuto, K.M., Viana, G.S.B., Moraes, M.E.A, Moraes, M.O. and Pessoa, C. (2003) Antiproliferative Effects of Several Compounds Isolated from Amburana cearensis A C Smith. Naturforsch, 58, 675-680.

https://doi.org/10.1515/znc-2003-9-1014

[15] Canuto, K.M. and Silveira, E.R. (2006) Constituintes químicos da casca do caule de Amburana cearensis A C Smith. [Chemical Constituents of the Bark of the Stem of Amburanacearensis A C Smith.] Química Nova, 29, 1241-1243. https://doi.org/10.1590/S0100-40422006000600018

[16] Pouchert, C.J. and Behnke, J. (1993) The Aldrich Library of ${ }^{13} \mathrm{C},{ }^{1} \mathrm{H}$ FT NMR Spectra. Aldrich Chemical Company, Milwaukee, 2.

[17] Canuto, K.M. (2007) Aspectos químicos de estudo interdisciplinar (Agronomia Química-Farmacologia) de A. cearensis AC Smith. Tese, Universidade Federal do Ceará, 302 p.

[18] Bravo, J.A., Sauvain, M., Gimenez, A., Munoz, V.O., Callapa, J., Le Men-Olivier, L., Massiot, G. and Lavand, C. (1999) Bioactive Phenolic Glycosides from Amburana cearensis. Phytochemistry, 50, 71-74.

[19] Martins, A.B. (2010) Avaliação do potencial antileishmania de compostos naturais isoladas de ácido úsnico, cumarina, quercetina e reserpina isolada sobre as formas promastigotas e amastigotas de Leishmania chagasi. Dissertação, Universidade Federal da Paraíba, João Pessoa, 123 p.

[20] Brezan, M.A., Ferreira, I.C., Nakamura, C.V., Nakamura, T.U., Filho-Dias, B.P. and Cortez, D.A.G. (2007) Antileishmanial Activity of Crude Extract and Coumarin from Calophyllun Brasiliense Leaves against Leishmania amazonensis. Parasitology Research, 101, 715-722. https://doi.org/10.1007/s00436-007-0542-7

[21] Shapira, M. and Zinoviev, A. (2011) Leishamania Parasites Act as a Trojan Horse That Paralyzes the Translation System of Host Macrophages. Cell Host \& Microbe, 9, 257-259.

[22] Cunningham, A.C. (2002) Parasitic Adaptive Mechanisms in Infection by Leishmania. Experimental and Molecular Pathology, 72, 132-141. https://doi.org/10.1006/exmp.2002.2418

[23] Antoine, J.C., Prima, E., Courret, N. and Lang, T. (2004) Leishmania spp: On the Interactions They Establish with Antigen-Presenting Cells of Their Mammalian Hosts. Advances in Parasitology, 58, 1-68.

[24] Olivier, M., Atayde, V.D., Isnard, A., Hassni, K. and Shio, M.T. (2012) Leishmania Virulence Factors: Focus on the Metalloprotease GP63 2012. Microbes and Infection, 14, 1377-1389. 
Submit or recommend next manuscript to OALib Journal and we will provide best service for you:

- Publication frequency: Monthly

- 9 subject areas of science, technology and medicine

- Fair and rigorous peer-review system

- Fast publication process

- Article promotion in various social networking sites (LinkedIn, Facebook, Twitter, etc.)

- Maximum dissemination of your research work

Submit Your Paper Online: Click Here to Submit

Or Contact service@oalib.com 